\title{
Bond characterization between concrete substrate and repairing SFRC using pull-off testing
}

\author{
Everaldo Bonaldo*, Joaquim A.O. Barros, Paulo B. Lourenço \\ Department of Civil Engineering, University of Minho, Azurém, P 4800-058 Guimarães, Portugal
}

Accepted 6 January 2005

Available online 14 March 2005

\begin{abstract}
In the last years, an emerging repair and strengthening technique for concrete slabs has been used, consisting of applying a thin layer of steel fibre reinforced concrete (SFRC) onto the slabs. The performance of the strengthened structural system depends on the bonding behaviour between old and new concretes. Adhesives based on epoxy resins currently make this liaison. The prices of these adhesives are quite different depending, mainly, on the percentage of pure resin that they include. In the present paper, three commercial adhesive compounds of distinct prices and properties were selected to bond concrete substrate and repairing SFRC. The bond behaviour was assessed from pull-off tests and the influence of the strength class of concrete substrate and repairing SFRC was analysed. Finally, the performance of the adhesives was evaluated considering both the bond strength and their prices.
\end{abstract}

(C) 2005 Elsevier Ltd. All rights reserved.

Keywords: Epoxy/epoxides; Concrete; Fibres; Repair; Pull-off test

\section{Introduction}

In the last years, the Near Surface Mounted (NSM) strengthening technique has been used, with remarkable efficiency, to increase the flexural [1] and the shear resistance of concrete elements [2]. The NSM technique is based on introducing laminate strips of carbon fibre reinforced polymer (CFRP) into slits made on the concrete cover of the elements to be strengthened. The NSM technique is well adjusted to increase the flexural resistance of concrete slabs. However, if the concrete of the slab has reduced compression strength, the increment of the flexural resistance that NSM can provide is limited by the maximum allowable compression strain in the most compressed concrete fibre. As a result of this restriction, the maximum tensile stress in the CFRP is a low percentage of its tensile strength, being questionable

\footnotetext{
*Corresponding author. Tel.: + 351253510200 ; fax: +351253510217 .

E-mail address: bona@civil.uminho.pt (E. Bonaldo).
}

the profitability of this strengthening technique in these cases. To overcome this limitation, a layer of steel fibre reinforced concrete (SFRC) can be bonded to the existent concrete at the compression surface, using an adhesive compound [3]. Since a thin layer is enough for the aforementioned purpose, the shrinkage and the temperature variation can induce uncontrolled cracking in the concrete of this layer. Adding steel fibres to concrete, the post-cracking residual stress can be increased in order to prevent the formation of uncontrolled crack patterns [4].

The bond performance between the existent and repair concretes plays an important role on the efficacy of this strengthening strategy. The present work deals with the main aspects related to the bond between concrete of distinct ages and properties, and is part of a more comprehensive research project involving the use of CFRP and discrete steel fibres for the strengthening and rehabilitation of concrete slabs.

The use of thin overlays of cementitious, resinous and polymer-modified cementitious materials for the 
strengthening and rehabilitation of concrete pavements, concrete bridges and asphalt pavements is well documented [5-8].

The development and maintenance of a sound bond between the overlay and the existing concrete substrate is an essential requirement to assure high strengthening performance. If sufficient adhesion is achieved, the strengthened structure behaves monolithically, being the materials effectively being mobilized [6-8].

The pull-off test method is one of the tensile test methods commonly used to assess the adhesion between the repair overlay and the existing concrete substrate. According to the ASTM D4541 standard [9], the general pull-off test is performed by fixing, with an adhesive, a loading fixture (disk) to the surface of the coating. After the adhesive has hardened, a testing apparatus is attached to the loading fixture and aligned, in order to apply a tensile force normal to the surface to be tested. The force applied to the loading fixture is then gradually increased in a manner as smooth and continuous as possible, using a specified loading rate. Failure occurs along the weakest plan within the system comprised of the test fixture, adhesive, repair overlay, bond surface between overlay and substrate, and substrate.

Unlike bond test methods of restricted use in laboratory, the pull-off test can be easily used in the field evaluation of the bond strength between repair material and parent concrete in a structure. A notable limitation of this type of test is its relative poor precision, evidenced by the large variation values obtained with different types of apparatus. Since pulloff strength measurements depend on instrumental parameters, results obtained from different devices may not be comparable [7,9].

In a concrete patch repair, failures can occur at the substrate concrete, at the bond interface, at the overlay, at the epoxy used to bond the disk to the core, or as a combination of these failures modes. The mode of failure and the pull-off strength provide valuable information about the appropriateness of repair system. The magnitude of the tensile force and the location of the fracture surface give some information of the performance of the repair system (overlay and adhesive). When failure only mobilizes adhesion material, the pull-off test provides a true indication of the bond strength. In this case, the ultimate load is a direct measure of the adhesion between the overlay and the concrete substrate. Failures at other locations indicate that the strength of the adhesive material is larger than the tensile strength of the substrate concrete and concrete overlay. When failure occurs between the disk and the overlay surface, there is an adhesive failure. In this case, if the result is lower than the average of the other results, it should be discarded, otherwise it can be taken into account. An epoxy failure should be a rare occurrence. If failure occurs in the overlay material, the repair material is the weakest part of the system. This is referred as a cohesive failure of the overlay. Finally, if the fracture surface occurs in the concrete substrate, the repair system can be considered adequate. This is often referred as a cohesive failure of the substrate. In this case, the pull-off strength is related to the tensile strength of the concrete substrate. In some cases, the failure occurs partially along the bond surface and partially in either the overlay or concrete substrate, and the fracture surface is a combination of two or more of the aforementioned failures modes [10,11].

In [10], a range of bond strength to qualify the test results is presented: excellent for bond strength $\geqslant 2.1 \mathrm{~N} /$ $\mathrm{mm}^{2}$, very good for $1.7-2.1 \mathrm{~N} / \mathrm{mm}^{2}$, good for $1.4-1.7 \mathrm{~N} /$ $\mathrm{mm}^{2}$, fair $0.7-1.4 \mathrm{~N} / \mathrm{mm}^{2}$ and poor for bond strength less than $0.7 \mathrm{~N} / \mathrm{mm}^{2}$.

\section{Scope}

This paper presents and analyses the results of an experimental research program aiming at investigating the effect of the strength class of the concrete substrate and the concrete overlay on the adhesion performance between these materials. The profitability of three commercially available bond products was assessed. The influence of the loading rate on the pull-off strength was also analysed. The experimental program was composed by three test groups, each one of distinct concrete strength class for the substrate. Each group is constituted by two series of different concrete strength classes for the overlay. To avoid the tendency of the failure at the lower strength class of the substrate, a maximum difference of one strength class was adopted for the concrete of the overlay and the substrate. The concrete overlay was always reinforced with steel fibres. Further details regarding the present study can be found elsewhere [12].

\section{Materials}

\subsection{Bond products}

Epoxy resin is widely used to bond materials used in construction industry, namely, concrete, masonry units, wood, glass, and metals. Epoxy resin is also a good adhesive to bond fresh to hardened concrete. Bonding fresh concrete overlay to an existing concrete slab is an example of such application [13].

Three types of epoxy-based bond agents were selected to bond fresh SFRC overlay to hardened concrete substrate, namely, two epoxy resin-based products (P1 and P2), and one epoxy resin- and cement-based product (P3). Table 1 shows some summarized information about the bond products extracted from 
manufacturer guidelines [14]. The bond P1 and P2 coating materials were applied onto dry and clean concrete, i.e., free from surface contaminants such as dust, laitance, oil or grease, following the manufacturer's specifications. To evaluate the influence of the surface conditions on the bond coat material, P3 was applied onto two types of substrate surface: dry surface and saturated surface. Since the manufacturer recommends applying the bond coat material P3 on saturated surface, the dry surface state was aimed at reproducing the real situation, verified in construction plants, where sometimes saturated condition is not completely guaranteed. The proportions adopted for each component are in agreement with the manufacturer's specifications [14].

\subsection{Concrete substrate and concrete overlay}

Using the Faury concrete mix design method [15] $\mathrm{C} 16 / 20, \mathrm{C} 35 / 45$ and $\mathrm{C} 55 / 67$ strength concrete classes were designed for the substrate, and $\mathrm{C} 20 / 25, \mathrm{C} 25 / 30$, C35/45, C45/55, C55/67 and C60/75 strength classes of SFRC were conceived for the overlay. All the strength concrete classes were classified according to CEB-FIP [16] concrete grades. Untreated aggregates, available in the Northern Region of Portugal (Minho), were used in the composition of concretes. To reinforce the concrete overlay hooked ends DRAMIX ${ }^{\circledR}$ RC-80/60-BN steel fibres were used, this fibre has a length $\left(l_{\mathrm{f}}\right)$ of $60 \mathrm{~mm}$, a diameter $\left(d_{\mathrm{f}}\right)$ of $0.75 \mathrm{~mm}$, an aspect-ratio $\left(l_{\mathrm{f}} / d_{\mathrm{f}}\right)$ of 80 and a yield strength of about $1100 \mathrm{~N} / \mathrm{mm}^{2}$ [17]. In previous works it was verified that this fibre has high performance since significant increase in the ultimate load bearing capacity of the structural concrete elements was obtained $[18,19]$.

Table 2 shows the mix proportion of the designed concretes and their main properties. The Rheobuild ${ }^{\circledR}$ 1000 superplasticizer of MBT is a weight percentage of the binder (cement, $\mathrm{C}$, in the concrete substrates; and cement and fly ash, FA, in the concretes for the overlay). It is noted that with very few exceptions the obtained compressive value is adequate with respect to the planned concrete class.

\section{Test set-up}

\subsection{Preparation of the specimens}

Unreinforced concrete slabs of $300 \mathrm{~mm} \times 650 \mathrm{~mm}$, with $80 \mathrm{~mm}$ thickness, were used as concrete substrate. For each batch of concrete, three cylindrical concrete specimens, measuring $150 \mathrm{~mm}$ in diameter and $300 \mathrm{~mm}$ long, were cast. Burlap sacks were placed over the slabs and specimens and were maintained wet for 2 days. After this curing phase, the slabs and the cylindrical specimens were demoulded and maintained in normal laboratory conditions. When the concrete substrate attained 28 days of age, the top surface (casting surface) of the slab specimen was treated. Fig. 1(a) and (b) show a specimen before surface treatment and the equipment used to rough the surface. The process of roughing the top surface of the concrete substrate has the purpose of removing a very thin layer of the surface, in order to remove grease, oils, free particles, laitance or dirt, as well as producing an irregular surface. The bond product was then applied and the fresh concrete overlay was cast (see Fig. 1). The procedures to bond the fresh SFRC overlay to the hardened concrete were in accordance to the manufacturer's specifications [14] and the ACI guidelines [20-22]. Previous research dealing with the combined use of CFRP and SFRC materials for structural strengthening has shown that a thickness of $30 \mathrm{~mm}$ for the SFRC overlay can be very effective [3]. Therefore, in the present work, this thickness was considered for the SFRC overlay. To consolidate the SFRC overlay, a mini slipform paver was used (see Fig. 1(h)). The mini slipform intends to simulate the real conditions of compaction of a thin SFRC overlay. Similarly to the substrate concrete, three cylindrical concrete specimens $(150 \mathrm{~mm} \times 300 \mathrm{~mm})$ for each batch of SFRC were cast and tested in compression at 28 days of age. The aforementioned curing process was also followed for the thin SFRC overlay and cylindrical concrete specimens. When the concrete overlay attained an age of about 28 days, the partial core was drilled and the pull-off tests were carried out.

\subsection{Pull-off test method and equipment}

When compared to other tests, the pull-off test is the simplest and most popular tensile bond test (see Fig. 2(a)) for measuring the adhesion properties, both on site for quality control and, in the laboratory, to evaluate the material properties and failure modes $[6,7,23]$. To evaluate the adhesion strength of an adhesive material that bonds a concrete overlay to an existing concrete substrate, the pull-off test with a partial coring technique is usual. However, this test can be affected by some factors such as the coring depth into substrate, the floor thickness and the strength class of the concrete substrate [23].

As mentioned previously, the pull-off test involves the application of a direct tensile load $\left(F_{\mathrm{T}}\right)$ to a partial core that mobilizes the repair material, the bond line and a portion of the substrate until failure occurs. The tensile load is applied to the partial core through the use of a metal, bronze or aluminium disk with a pull pin, bonded to the overlay with an epoxy resin. A loading device, with a reaction frame, applies the load to the pull pin at a constant rate. After performing the test, the failure mode has to be carefully analysed since it provides 
Table 1

Data extracted from commercial datasheet for the bond products [15]

\begin{tabular}{|c|c|c|c|}
\hline Product & $\mathrm{P} 1$ & $\mathrm{P} 2$ & \\
\hline Commercial name & $\mathrm{Icosit}^{\circledR} \mathrm{K} 101$ & Sikadur $^{\circledR} 32 \mathrm{~N}$ & Sikatop $^{\circledR}$ Armatec 110 EpoCem $^{\circledR}$ \\
\hline Brief description & $\begin{array}{l}\text { Epoxy resin-base bond coat, free } \\
\text { from solvents, available in two } \\
\text { components. Ensures the perfect } \\
\text { bond between freshly concrete } \\
\text { and old concrete }\end{array}$ & $\begin{array}{l}\text { Epoxy resins-base bond coat } \\
\text { available in two components, free } \\
\text { from solvents. When applied on the } \\
\text { hardened concrete surface provides } \\
\text { perfect bond between freshly and old } \\
\text { concrete }\end{array}$ & $\begin{array}{l}\text { Anticorrosive coating and adhesive } \\
\text { agent cement and modified epoxy } \\
\text { resin-base, available in three } \\
\text { components }\end{array}$ \\
\hline Consumptions & $\begin{array}{l}0.5-2 \mathrm{~kg} / \mathrm{m}^{2}, \text { depending on } \\
\text { porosity and roughness of the } \\
\text { substrate surface. }\end{array}$ & $\begin{array}{l}0.3-0.8 \mathrm{~kg} / \mathrm{m}^{2} \text {, depending on nature } \\
\text { and porosity and also temperature }\end{array}$ & $\begin{array}{l}\text { When used as adhesion agent, at } \\
\text { least, } 1.5 \mathrm{~kg} / \mathrm{m}^{2} \text {, can be higher if the } \\
\text { concrete substrate is very irregular }\end{array}$ \\
\hline Specific gravity & Approximately $1.8 \mathrm{~kg} / 1$ & Approximately $1.4 \mathrm{~kg} / 1$ & $\begin{array}{l}\text { Approximately (at } 20^{\circ} \mathrm{C} \text { ) } \mathrm{A}+\mathrm{B}+\mathrm{C} \\
\operatorname{mix} 2.0 \mathrm{~kg} / 1\end{array}$ \\
\hline \multirow[t]{2}{*}{ Bond strength } & $\begin{array}{l}\text { To concrete: } 3 \mathrm{~N} / \mathrm{mm}^{2} \text { (concrete } \\
\text { failure) }\end{array}$ & $\begin{array}{l}\text { To concrete: } 2.5-3.0 \mathrm{~N} / \mathrm{mm}^{2} \\
\text { (concrete failure) }\end{array}$ & To sandblasted concrete: $2-3 \mathrm{~N} / \mathrm{mm}^{2}$ \\
\hline & To sandblasted steel: $20 \mathrm{~N} / \mathrm{mm}^{2}$ & To steel: $18-20 \mathrm{~N} / \mathrm{mm}^{2}$ & To steel: $1-2 \mathrm{~N} / \mathrm{mm}^{2}$ \\
\hline Mechanical resistance & $\begin{array}{l}\text { Compressive strength: } 90 \mathrm{~N} / \mathrm{mm}^{2} \\
\text { Flexural strength: } 45 \mathrm{~N} / \mathrm{mm}^{2}\end{array}$ & $\begin{array}{l}\text { Compressive strength: } 60-70 \mathrm{~N} / \mathrm{mm}^{2} \\
\text { Compressive strength: } 18-20 \mathrm{~N} / \mathrm{mm}^{2} \\
\text { Flexural strength: } 30-35 \mathrm{~N} / \mathrm{mm}^{2}\end{array}$ & - \\
\hline
\end{tabular}

information about what was really measured [23]. Fig. 2(a) illustrates the principle of the pull-off test, and sketches a typical failure surface for the case of overlay and adhesion strength higher than the pull-off strength of the concrete substrate. The pull-off strength $\left(S_{\mathrm{PO}}\right)$ is defined as the tensile (pull-off) force $\left(F_{\mathrm{T}}\right)$ divided by the area of the fracture surface $\left(A_{\mathrm{f}}\right)$ :

$S_{\mathrm{PO}}=\frac{F_{\mathrm{T}}}{A_{\mathrm{f}}}$.

There are other different types of in situ direct tensile tests proposed in the last years to evaluate the bond properties and the performance of repair materials in general. However, the partial core pull-off test is considered the best one available for evaluating the bond strength in the field [7]. A brief review of the most common tensile bond tests, as well as, an evaluation of three types of in situ direct tensile testing equipment is provided by [7]. One of the devices evaluated in this study includes the testing equipment used here, namely the Proceq DYNA Z15, with a $48 \mathrm{~mm}$ diameter disk (see Fig. 2(b)). This equipment has a load capacity of $16 \mathrm{kN}$, an accuracy of $2 \%$ and a resolution of $0.10 \mathrm{~N} / \mathrm{mm}^{2} \mathrm{~s}^{-1}$ [24]. The pull-off tests were conducted complying with the general procedures described in the standards $[9$, 25-27].

According to [7], an important issue associated with pull-off tests is the depth of the core drilling into the existing concrete substrate, and ignoring the effect of the drilled depth may be one of the main causes of the difficulties in reproducing and comparing test results. The partial core is usually cut by means of a rotary core cutting drill with diamond bits. To avoid cutting damage, it is important to ensure uniform pressure when the core is being drilled through the concrete overlay into the substrate [28]. This operation is mostly dependent on workmanship, thus it is essential that a skilled operator carry out the works. Reducing the core diameter leads to an increasing influence of internal defects (in the concrete volume) in the specimen pull-off strength. Additionally, when reducing the core diameter, the ratio of cut surface area to volume increases and, at the same time, the intensity of damages occurring in the partial core drilling process increases [28]. Thus, it is expected that pull-off concrete strength decreases when reducing core diameter. In general, the $50 \mathrm{~mm}$ core diameter is the most common in the specifications, being the maximum aggregate size not taken into account by the standards in the definition of the core diameter. A minimum ratio between the core diameter and the large aggregate ratio of three is generally recognized as acceptable for testing drilled concrete cores [28].

In this work, a core diameter of $48 \mathrm{~mm}$ with approximately $15 \pm 5 \mathrm{~mm}$ of drilling depth into the substrate was adopted, which are commonly applied values [6]. Before gluing the disk using an epoxy resin, a very thin layer of the concrete surface was removed by a stone wear machine appropriate for this purpose, see Fig. 1(l) and (m). Afterwards, the concrete surface was cleaned and degreased, and the disk was cleaned with alcohol. Failure in the adhesive-concrete interface or disk-adhesive interface was never verified, confirming the excellent performance of this proceeding. Due to practical and economic reasons bronze disks have been 

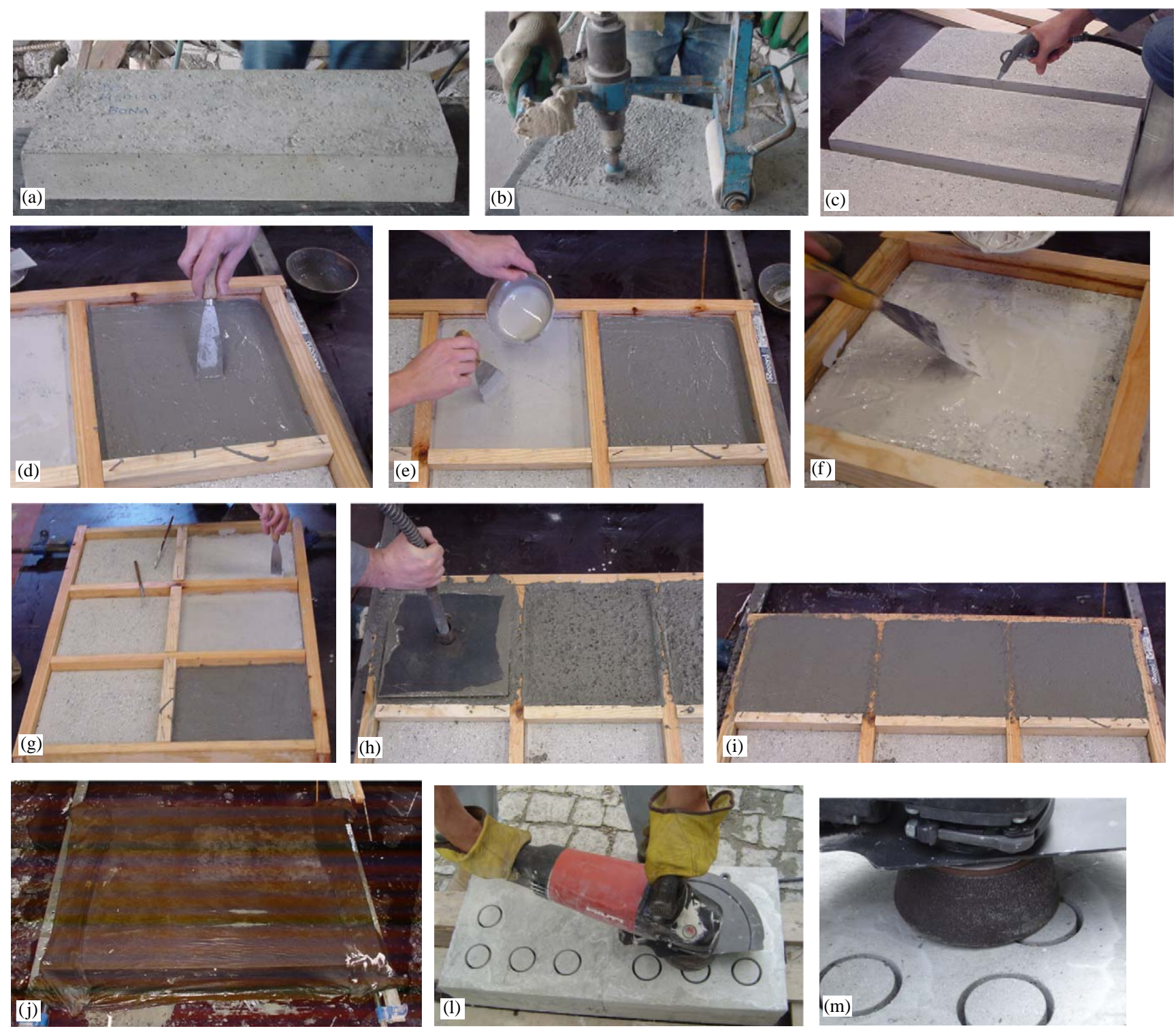

Fig. 1. Main steps of the bond process of the SFRC overlay: (a) the specimen surface before roughing, (b) the rough machine used, (c) cleaning the top surface with compressed air jet, (d) placing the bond product P3, (e) placing the bond product P2, (f) placing the bond product P1, (g) overview of the bond coats before casting the fresh SFRC overlay, (h) consolidating of the SFRC, (i) final aspect of the finished surface, (j) curing with wet burlap, (l) overview of the machine for removal of a very thin layer from the concrete surface, and (m) detail of the stone wear device.

selected for all tests. Fig. 2(c) represents the position of the partial cores.

The loading rate used in the pull-off tests carried out with DYNA Z15 was $0.05 \pm 0.01 \mathrm{~N} / \mathrm{mm}^{2} \mathrm{~s}^{-1}$, in agreement with the British and European Standards [25,26]. It is generally accepted that higher loading rates result in higher failure loads [6]. For the pull-off test, this effect, however, was not well investigated. To assess the effect of the loading rate on the pull-off strength, tests were also carried out at 0.02 and $0.15 \mathrm{~N} / \mathrm{mm}^{2} \mathrm{~s}^{-1}$.

Finally, load eccentricity is another factor that affects the test results. According to [6], the load eccentricity in a partial core pull-off test depends basically on the orthogonality of the core drilling (relatively to the substrate) and accuracy in positioning the metal disk on top of the partial core. In this way, if the orthogonality of the core drilling is not guaranteed, the eccentricity of the loading will increase with the deepness of the core drilling. It is also believed that by increasing the drilling depth, the core damage generated by the vibration of the cutting drill machine increases.

\section{Results}

\subsection{Tests performed manually with Proceq DYNA Z15}

Table 3 shows the pull-off test results for all series, composed by the average pull-off strength, $S_{\mathrm{PO}, \mathrm{m}}$, and 
Table 2

Mix proportions and main properties of the concretes

Mix proportions and main properties of the ordinary concrete

Components

B1 (C16/20)

B2 (C35/45)

B3 $(\mathrm{C} 55 / 67)$

Cement I $42.5 R\left(\mathrm{~kg} / \mathrm{m}^{3}\right) \quad 225$

Fine river sand $\left(\mathrm{kg} / \mathrm{m}^{3}\right) \quad 356$

Coarse river sand $\left(\mathrm{kg} / \mathrm{m}^{3}\right) \quad 597$

Fine aggregate $\left(\mathrm{kg} / \mathrm{m}^{3}\right) \quad 444$

Coarse aggregate $\left(\mathrm{kg} / \mathrm{m}^{3}\right) \quad 566$

Superplasticizer (\%) 2.5

$\mathrm{W} / \mathrm{C}$ ratio $\quad 0.68$

Slump (mm)

60

$\mathrm{fc}_{28 \mathrm{~d}}{ }^{\mathrm{a}}\left(\mathrm{N} / \mathrm{mm}^{2}\right)$

22.32

$\begin{array}{ll}300 & 425 \\ 353 & 337 \\ 591 & 564 \\ 439 & 419 \\ 560 & 535 \\ 2.5 & 2.5 \\ 0.45 & 0.30 \\ 225 & 250 \\ 42.59 & 60.82\end{array}$

Mix proportions and main properties of the steel fibre -reinforced concrete

For bond coat applied on dry substrate surface

\begin{tabular}{|c|c|c|c|c|c|c|}
\hline Components & $\mathrm{C} 1(\mathbf{C 2 0} / \mathbf{2 5})$ & $\mathrm{C} 2(\mathbf{C 2 5} / \mathbf{3 0})$ & C3 (C35/45) & $\mathrm{C} 4(\mathbf{C 4 5} / 55)$ & C5 (C55/67) & C6 (C60/75) \\
\hline Cement I $42.5 R\left(\mathrm{~kg} / \mathrm{m}^{3}\right)$ & 220 & 290 & 290 & 360 & 400 & 460 \\
\hline Fly ash $\left(\mathrm{kg} / \mathrm{m}^{3}\right)$ & 22 & 29 & 29 & 36 & 40 & 46 \\
\hline Fine river sand $\left(\mathrm{kg} / \mathrm{m}^{3}\right)$ & 349 & 339 & 339 & 328 & 322 & 306 \\
\hline Coarse river sand $\left(\mathrm{kg} / \mathrm{m}^{3}\right)$ & 584 & 567 & 567 & 549 & 540 & 512 \\
\hline Fine aggregate $\left(\mathrm{kg} / \mathrm{m}^{3}\right)$ & 434 & 422 & 422 & 408 & 401 & 381 \\
\hline Coarse aggregate $\left(\mathrm{kg} / \mathrm{m}^{3}\right)$ & 554 & 538 & 538 & 521 & 512 & 486 \\
\hline Superplasticizer $(\%)$ & 2.5 & 2.5 & 2.5 & 2.5 & 2.5 & 2.5 \\
\hline Steel fibre $\left(\mathrm{kg} / \mathrm{m}^{3}\right)$ & 30 & 30 & 30 & 30 & 30 & 30 \\
\hline $\mathrm{W} /(\mathrm{C}+\mathrm{FA})$ ratio & 0.65 & 0.48 & 0.48 & 0.37 & 0.32 & 0.31 \\
\hline $\operatorname{Slump}^{\mathrm{b}}(\mathrm{mm})$ & 110 & 200 & 180 & 210 & 220 & 250 \\
\hline $\mathrm{fc}_{28 \mathrm{~d}}{ }^{\mathrm{a}}\left(\mathrm{N} / \mathrm{mm}^{2}\right)$ & 25.87 & 32.08 & 41.50 & 53.51 & 62.54 & 66.81 \\
\hline \multicolumn{7}{|c|}{ For bond coat applied on saturated substrate surface } \\
\hline Components & $\mathrm{C}^{\prime}(\mathbf{C 2 0} / 25)$ & $\mathrm{C} 2^{\prime}(\mathbf{C 2 5} / 30)$ & $\mathrm{C} 3^{\prime}(\mathbf{C} 35 / 45)$ & $\mathrm{C} 4^{\prime}(\mathbf{C 4 5} / 55)$ & $\mathrm{C}^{\prime}(\mathrm{C} 55 / 67)$ & \\
\hline Cement I $42.5 R\left(\mathrm{~kg} / \mathrm{m}^{3}\right)$ & 220 & 280 & 290 & 400 & 475 & \\
\hline Fly ash $\left(\mathrm{kg} / \mathrm{m}^{3}\right)$ & 22 & 28 & 29 & 40 & 48 & \\
\hline Fine river sand $\left(\mathrm{kg} / \mathrm{m}^{3}\right)$ & 347 & 329 & 339 & 322 & 315 & \\
\hline Coarse river sand $\left(\mathrm{kg} / \mathrm{m}^{3}\right)$ & 581 & 552 & 567 & 540 & 528 & \\
\hline Fine aggregate $\left(\mathrm{kg} / \mathrm{m}^{3}\right)$ & 432 & 410 & 422 & 401 & 393 & \\
\hline Coarse aggregate $\left(\mathrm{kg} / \mathrm{m}^{3}\right)$ & 551 & 523 & 538 & 512 & 501 & \\
\hline Superplasticizer $(\%)$ & 2.5 & 2.5 & 2.5 & 2.5 & 2.5 & \\
\hline Steel fibre $\left(\mathrm{kg} / \mathrm{m}^{3}\right)$ & 30 & 30 & 30 & 30 & 30 & \\
\hline $\mathrm{W} /(\mathrm{C}+\mathrm{FA})$ ratio & 0.67 & 0.57 & 0.48 & 0.34 & 0.25 & \\
\hline Slump $^{\mathrm{b}}(\mathrm{mm})$ & 170 & 245 & 230 & 225 & 275 & \\
\hline $\mathrm{fc}^{\mathrm{a}}\left(\mathrm{N} / \mathrm{mm}^{2}\right)$ & $27.36(55)$ & $38.48(52)$ & $58.46(49)$ & $66.67(49)$ & $61.78(44)$ & \\
\hline
\end{tabular}

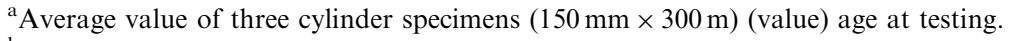

${ }^{\mathrm{b}}$ Slump before adding the steel fibres.

the coefficient of variation (COV). Here, the series is given according to the concrete mixtures defined in Table 2. The analysis of the COV of four test specimens for each bond material presented shows that it varies from $3.43 \%$ to $38.87 \%$. The COVs for the series $\mathrm{B} 1 \mathrm{C1}^{\prime} \mathrm{P} 3, \mathrm{~B} 2 \mathrm{C} 3 \mathrm{P} 3, \mathrm{~B} 2 \mathrm{C} 4 \mathrm{P} 3, \mathrm{~B} 3 \mathrm{C} 5 \mathrm{P} 3, \mathrm{~B} 3 \mathrm{C}^{\prime} \mathrm{P} 3$ and $\mathrm{B} 3 \mathrm{C} 6 \mathrm{P} 3$ are relatively high and suggest that the test data are quite variable, while the COVs for the other models are acceptable, taking into consideration this is a tensile test where significant scatter on the results is always expected. The authors believe that the higher values of COV are not only due to the lack of precision of the test method, but also due to the intrinsic heterogeneity of granular materials like concrete. The difficulty on assuring always equal test procedures also contributed for the large scatter.

The pull-off strength ratios ( $\mathrm{P} 2 / \mathrm{P} 1$ and $\mathrm{P} 2 / \mathrm{P} 3)$ and a profitability index $\left(R_{\mathrm{SC}_{i}}\right)$ comparison are also given in Table 3 . The analyses based on average pull-off strength demonstrate that for the six series the average pull-off strength obtained with bond material $\mathrm{P} 2$ is at least 1.11 and 1.46 (1.36) orders of magnitude higher in 

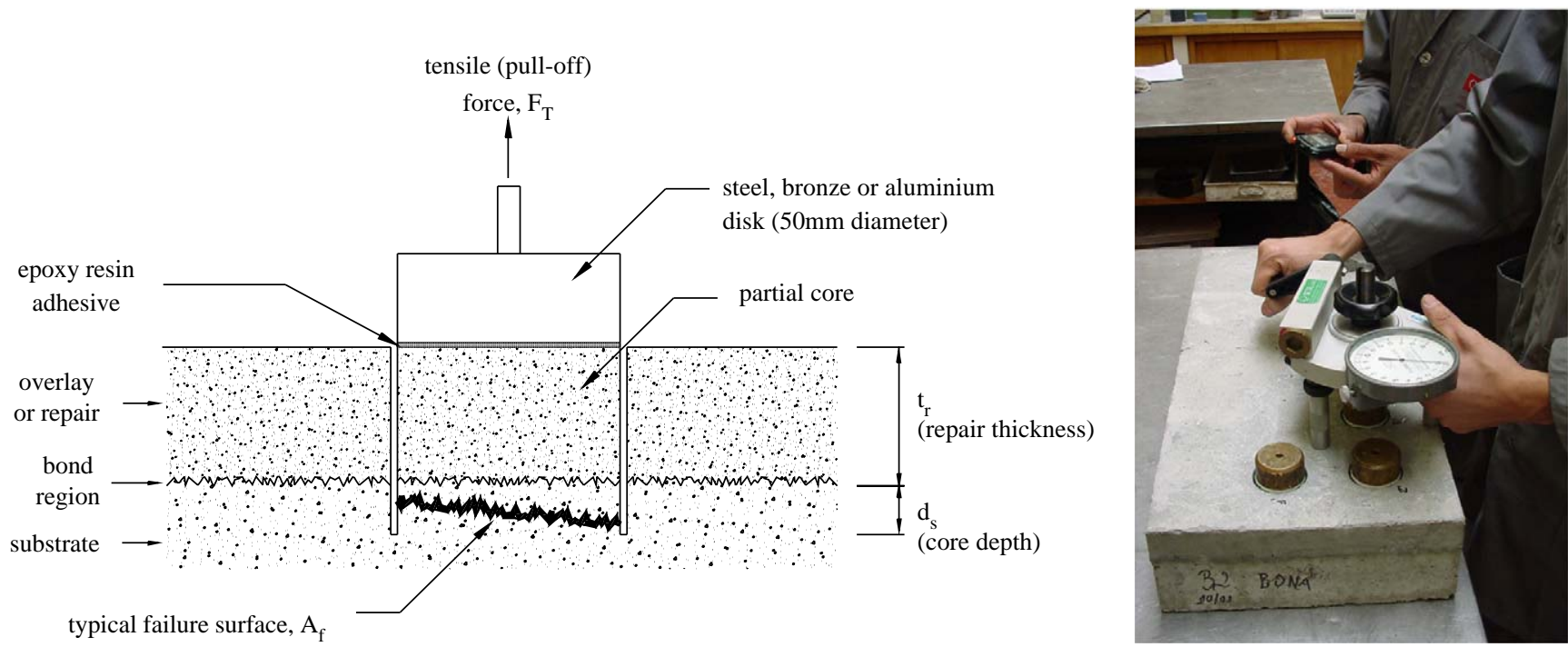

(a)

(b)
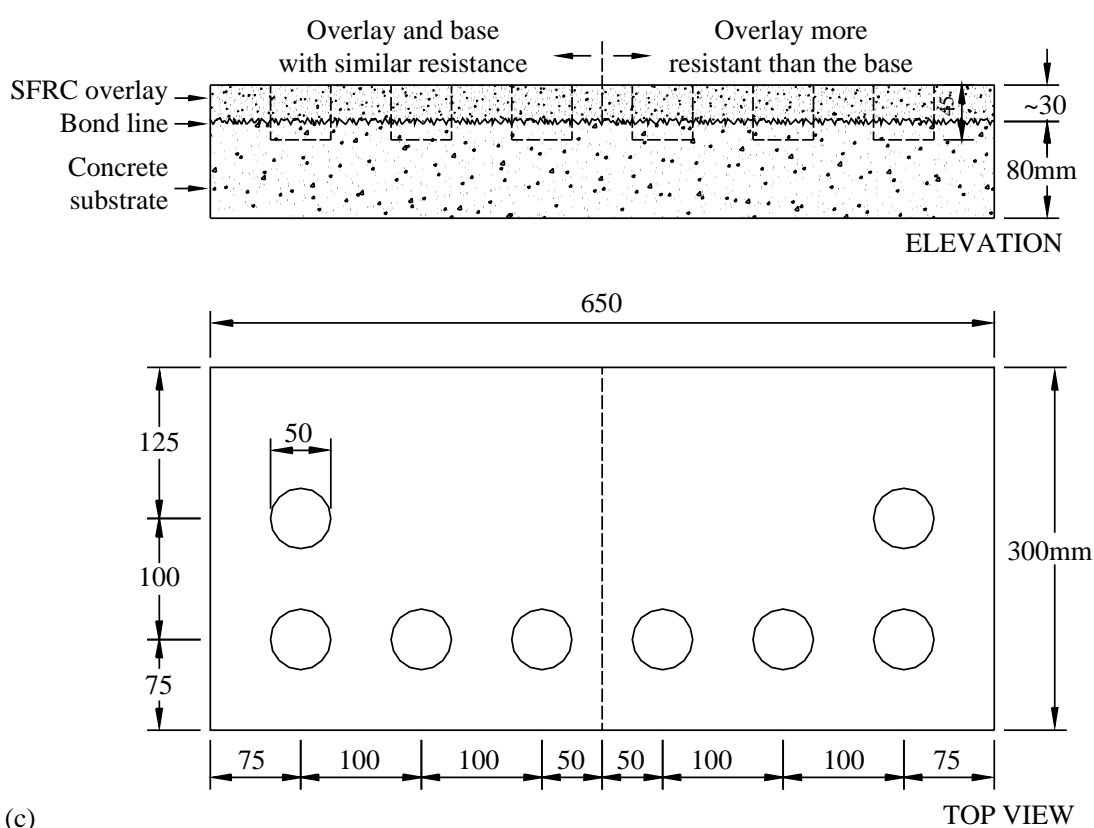

(c)

Fig. 2. Pull-off test: (a) schematic representation of pull-off test principle, (b) testing with Proceq DYNA Z15 device, and (c) location of the cores used for pull-off tests (units in millimetres).

comparison to the average pull-off strength obtained with P1 and P3 (and P3 with saturated substrate surface) bond materials, respectively.

From the analysis of Table 3 , it is verified that increasing the substrate strength the profitability index is increased for the three bond agents, meaning that the substrate plays a key role in the response. For the stronger substrate, the performance is twice the value registered in the weak substrate. The following expression was used for the computation of profitability index:

$R_{\mathrm{SC}_{i}}=\frac{S_{\mathrm{PO}_{i}} /\left(A_{\mathrm{PO}} d_{i}\right)}{C_{i}}$,

where $i$ is the bond coat product (i=1,2, and 3 ), $R_{\mathrm{SC}_{i}}$ is the profitability index $\left(\mathrm{N} / \mathrm{mm}^{2} / €\right), \quad S_{\mathrm{PO}_{i}}=$ average pull-off strength $\left(\mathrm{N} / \mathrm{mm}^{2}\right), A_{\mathrm{PO}}=$ area of the core with diameter of $48 \mathrm{~mm}\left(\mathrm{~mm}^{2}\right), d_{i}=$ bond coat dosage $\left(\mathrm{kg} / \mathrm{mm}^{2}\right)$, and $C_{i}=$ bond coat cost $(€ / \mathrm{kg})$. 
Table 3

Average pull-off strength, strength ratio and profitability index

\begin{tabular}{|c|c|c|c|c|c|c|c|c|}
\hline \multirow[t]{3}{*}{ Series } & \multicolumn{3}{|c|}{ Average pull-off strength, $\mathrm{S}_{\mathrm{PO}, \mathrm{m}}\left(\mathrm{N} / \mathrm{mm}^{2}\right)$} & \multicolumn{2}{|c|}{ Strength ratio } & \multicolumn{3}{|c|}{ Profitability index $\left(\mathrm{N} / \mathrm{mm}^{2} / €\right)^{\mathrm{a}}$} \\
\hline & \multicolumn{3}{|c|}{ Bond product } & \multirow[b]{2}{*}{$\mathrm{P} 2 / \mathrm{P} 1$} & \multirow[b]{2}{*}{$\mathrm{P} 2 / \mathrm{P} 3$} & \multirow[b]{2}{*}{$R_{\mathrm{SC} 1}$} & \multirow[b]{2}{*}{$R_{\mathrm{SC} 2}$} & \multirow[b]{2}{*}{$R_{\mathrm{SC} 3}$} \\
\hline & $\mathrm{P} 1$ & $\mathrm{P} 2$ & P3 & & & & & \\
\hline $\mathrm{B} 1 \mathrm{C} 1$ & $1.48(9.46)$ & $1.58(11.39)$ & $\begin{array}{l}1.12(8.04) \\
1.35^{(1)}(22.25)\end{array}$ & 1.07 & $\begin{array}{l}1.41 \\
1.17^{(1)}\end{array}$ & 119 & 674 & $\begin{array}{l}38 \\
46\end{array}$ \\
\hline $\mathrm{B} 1 \mathrm{C} 2$ & $1.61(12.42)$ & $1.83(15.30)$ & $\begin{array}{l}1.36(11.76) \\
1.43^{(2)}(17.46)\end{array}$ & 1.14 & $\begin{array}{l}1.35 \\
1.28^{(2)}\end{array}$ & 130 & 780 & $\begin{array}{l}47 \\
49\end{array}$ \\
\hline $\mathrm{B} 2 \mathrm{C} 3$ & $2.46(15.04)$ & $2.59(6.56)$ & $\begin{array}{l}1.69(24.26) \\
2.22^{(3)}(16.10)\end{array}$ & 1.05 & $\begin{array}{l}1.53 \\
1.17^{(3)}\end{array}$ & 198 & 1104 & $\begin{array}{l}58 \\
76\end{array}$ \\
\hline $\mathrm{B} 2 \mathrm{C} 4$ & $2.38(18.07)$ & $2.35(11.91)$ & $\begin{array}{l}1.61(24.84) \\
1.81^{(4)}(13.22)\end{array}$ & 0.99 & $\begin{array}{l}1.46 \\
1.30^{(4)}\end{array}$ & 191 & 1002 & $\begin{array}{l}55 \\
62\end{array}$ \\
\hline B3C5 & $3.21(3.43)$ & $4.20(6.43)$ & $\begin{array}{l}2.83(22.97) \\
2.57^{(5)}(20.51)\end{array}$ & 1.31 & $\begin{array}{l}1.48 \\
1.63^{(5)}\end{array}$ & 258 & 1791 & $\begin{array}{l}97 \\
88\end{array}$ \\
\hline B3C6 & $3.32(15.66)$ & $3.73(7.77)$ & $\begin{array}{l}2.47(38.87) \\
2.36^{(6)}(15.51)\end{array}$ & 1.12 & $\begin{array}{l}1.51 \\
1.58^{(6)}\end{array}$ & 267 & 1590 & $\begin{array}{l}85 \\
81\end{array}$ \\
\hline Average & & & & 1.11 & $\begin{array}{l}1.46 \\
1.36\end{array}$ & & & \\
\hline
\end{tabular}

${ }^{(1)} \mathrm{B} 1 \mathrm{Cl}^{\prime},{ }^{(2)} \mathrm{B} 1 \mathrm{C} 2{ }^{\prime},{ }^{(3)} \mathrm{B} 2 \mathrm{C} 2{ }^{\prime},{ }^{(4)} \mathrm{B} 2 \mathrm{C} 3^{\prime},{ }^{(5)} \mathrm{B} 3 \mathrm{C} 4{ }^{\prime},{ }^{(6)} \mathrm{B} 3 \mathrm{C} 5^{\prime}$ (value) coefficient of variation $(\mathrm{COV})=($ standard deviation $/$ average $) \times 100$.

${ }^{\mathrm{a}}$ Taking into account the bond coat dosage and the area of the core. The prices were provided by the manufacturer $(\mathrm{P} 1: 3.04 € / \mathrm{Kg}$; $\mathrm{P} 2$ : $1.44 € / \mathrm{Kg}$; P3: $5.09 € / \mathrm{Kg})$.

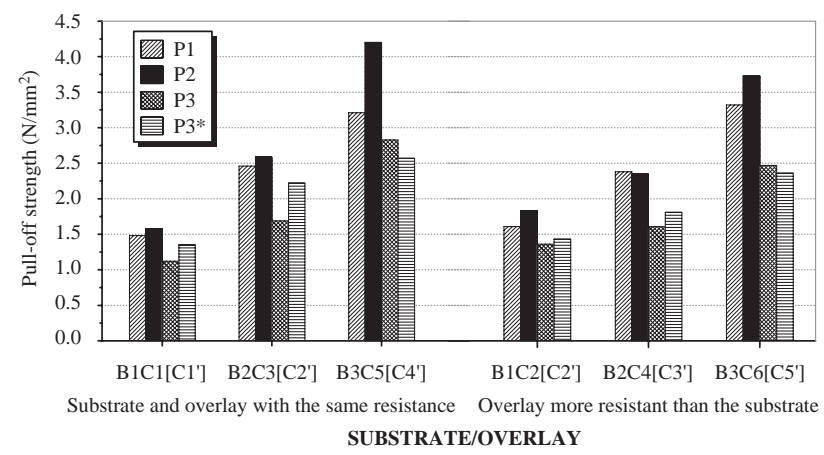

Fig. 3. Pull-off average strength for each substrate and overlay type (where P3* indicates bond P3 applied on saturate substrate surface).

The average pull-off strength values of four pull-off tests with DYNA Z15 device are depicted in Fig. 3, for all series. It can be observed that increasing the strength of the overlay does not lead to an increase in the pull-off strength, as expected. On the contrary, the strength of the substrate plays a major role in the pull-off strength. From the experimental data, it is also possible to observe that the pull-off strength for bond product $\mathrm{P} 3$ is relatively low in comparison with the results for $\mathrm{P} 1$ and $\mathrm{P} 1$, meaning that the bond product plays a role in the response. P2 bond product attained larger average pulloff strengths than the other bond products, independently of the substrate and overlay compressive strength (see Fig. 4(a) and (b)). Fig. 4(c) and (d) indicate linear increasing trend of pull-off strength with the compressive strength of concrete substrate and SFRC overlay.
A marginal benefit is verified when the bond coat product $\mathrm{P} 3$ is applied on saturated substrate surface for the cases of low and medium concrete class strength of

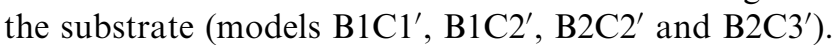
For the case of high concrete class strength of the substrate (models $\mathrm{B} 3 \mathrm{C} 4^{\prime}$ and $\mathrm{B} 3 \mathrm{C} 5^{\prime}$ ), a reduction in the pull-off strength was observed (see Fig. 4(a) and (b)). The substrate of these series was made using the highest concrete strength class, which offered higher resistance to the penetration of the water used to saturate the substrate surface, resulting in the formation of a water film that has decreased the bond strength between the two concrete materials.

Finally, the better profitability index was obtained for the bond coat material P2, independently of the substrate and overlay compressive strength.

As an example of the complex response of the pull-off test, Fig. 5 shows the fracture surface of core 2 of the model B1C1P2 (see [12]). The crack surface was initiated in the interface adhesive-concrete overlay from the zone where high percentage of voids and network voids were visible. This exceptional high percentage of voids might be related to the agglomeration and non-favourable fibre orientation. In spite of this apparent weakness, the pull-off strength of this specimen was the highest one of the specimens of its series. This extraneous result might be justified by the crack surface profile. In fact, after initiation at the adhesive-concrete overlay interface, the crack surface has crossed the adhesive layer, that has tensile strength much higher than the surrounding concrete materials, and ending at the concrete substrate, resulting in a tortuous crack surface profile of higher surface. All failure modes of the testing programme are 


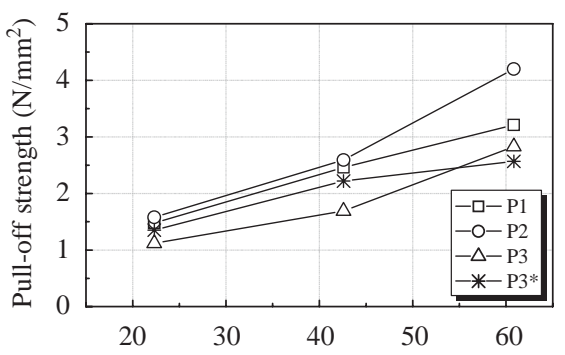

(a) Substrate compressive strength $\left(\mathrm{N} / \mathrm{mm}^{2}\right)$

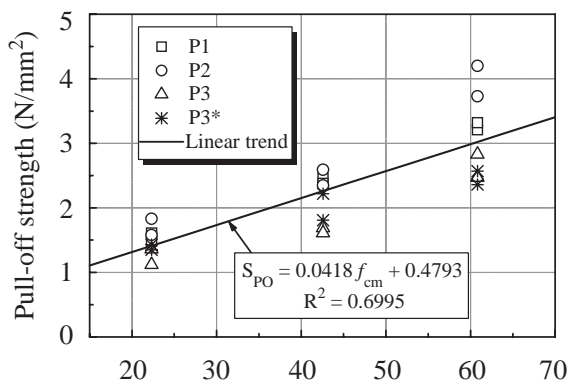

(c) Substrate compressive strength $\left(\mathrm{N} / \mathrm{mm}^{2}\right)$

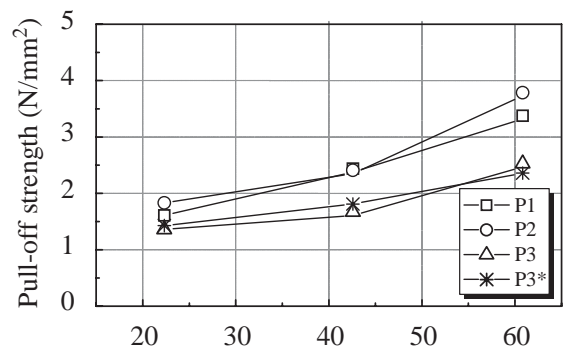

(b) Substrate compressive strength $\left(\mathrm{N} / \mathrm{mm}^{2}\right)$

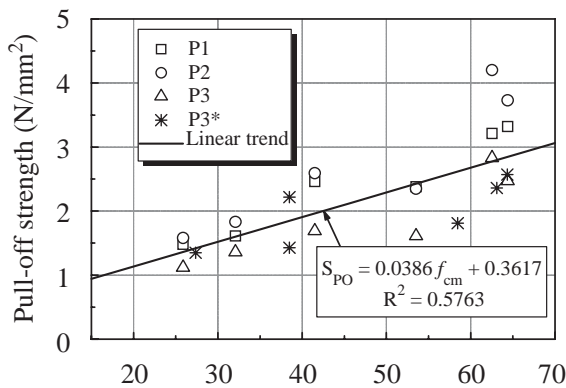

(d) Overlay compressive strength $\left(\mathrm{N} / \mathrm{mm}^{2}\right)$

Fig. 4. Pull-off test results: (a) pull-off average strength for concrete overlay and concrete substrate with similar compressive strength, (b) pull-off average strength for concrete overlay more resistant than the concrete base, (c) effect of substrate strength on the pull-off strength, and (d) effect of overlay strength on the pull-off strength (where P3* indicates bond P3 applied on saturated substrate surface).

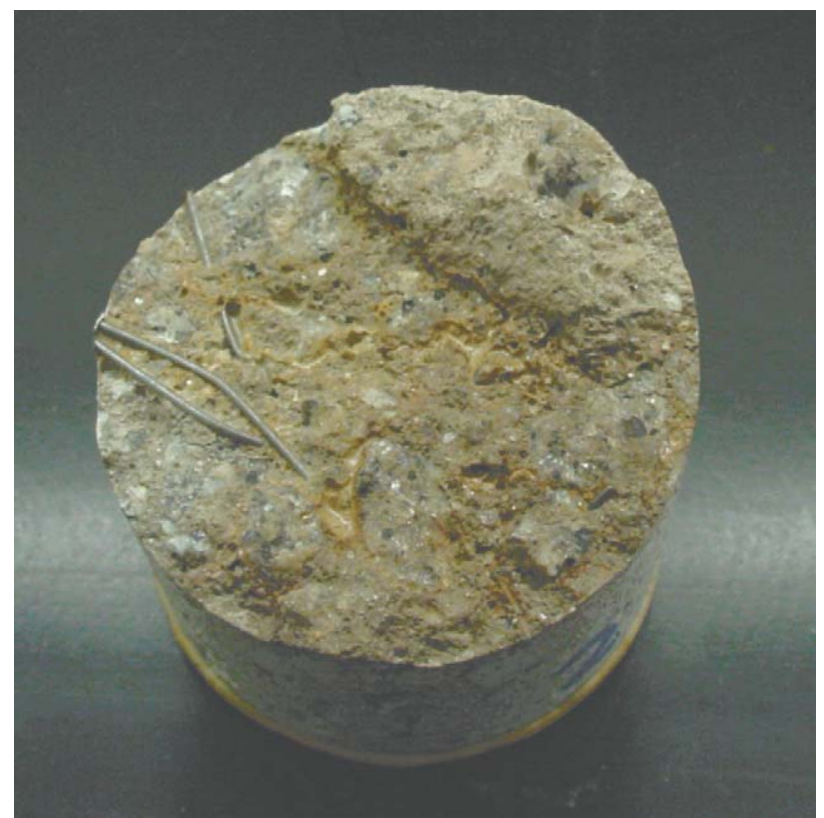

Fig. 5. Detail of the failure mode verified in one test of the model $\mathrm{B} 1 \mathrm{C} 1$ with bond coat $\mathrm{P} 2$.

summarized in Table 4. For a complete reference the reader is referred to [12].

\subsection{Assessing the influence of loading rate}

To evaluate the influence of the loading rate on the pull-off strength, pull-off tests were carried out using two stress rates $\left(0.02\right.$ and $\left.0.15 \mathrm{~N} / \mathrm{mm}^{2} \mathrm{~s}^{-1}\right)$. For this purpose, the bond product $\mathrm{P} 2$ was selected, since it was verified to be the most effective one. A servo-controlled hydraulic actuator with a load cell of $25 \mathrm{kN}$ capacity (accuracy of $0.1 \%$ ) was employed for these tests (see Fig. 6(a)).

For each of the six series of the experimental program, at least, 10 pull-off tests were carried out. The obtained average results are given in Fig. 6(b), where a trend for the increase of the pull-off strength with the increase of the stress rate is shown. However, a large scatter was found due to several factors such as difficulty on assuming equal perfect pull-off test conditions; influence of differential shrinkage and cyclic action of temperature variation (difficult to assure equal conditions, resulting distinct bond stresses in the interface between the two concrete layers); influence of the steel fibres distribution (impossible to guarantee equal conditions); and influence of fly ash addition.

Another relevant conclusion is that the test set-up strongly influences the results, as also given in [7,9]. When compared to the pull-off strength results from the hydraulic actuator, the DYNA Z15 apparatus has given higher values in some series and lower values in another series (see Fig. 6(b)).

\section{Summary and conclusions}

An experimental campaign was conducted in order to (a) investigate the effect of the concrete strength on 
Table 4

Summary of the modes of failure

\begin{tabular}{|c|c|c|}
\hline Model & Bond product & Failure mode recorded \\
\hline $\mathrm{B} 1 \mathrm{C} 1$ & $\begin{array}{l}1 \\
2 \\
3 \\
3^{(1)}\end{array}$ & $\begin{array}{l}\text { Combination of substrate failure, aggregate-paste bond failure and paste failure. Existence of voids on } \\
\text { the fracture surface } \\
\text { Failure in the bond-substrate interface } \\
\text { Substrate failure just below the bond-substrate interface (combination of paste failure, aggregate } \\
\text { failure and aggregate-paste bond failure), and bond-overlay interface failure (in the high spots part of } \\
\text { the substrate surface, i.e. in the stand out part of the coarse aggregates) }\end{array}$ \\
\hline B1C2 & $\begin{array}{l}3 \\
3^{(2)}\end{array}$ & $\begin{array}{l}\text { Combination of substrate failure, aggregate-paste bond failure and paste failure. Existence of voids on } \\
\text { the fracture surface } \\
\text { Combination of substrate failure, aggregate-paste bond failure, coarse aggregate failure and paste } \\
\text { failure. Existence of voids on the fracture surface } \\
\text { Failure in the bond-substrate interface } \\
\text { Substrate failure just below the bond-substrate interface (combination of paste failure, aggregate } \\
\text { failure and aggregate-paste bond failure), and bond-overlay interface failure (in the high spots part of } \\
\text { the substrate surface, i.e. in the stand out part of the coarse aggregates). Existence of voids on the } \\
\text { fracture surface }\end{array}$ \\
\hline $\mathrm{B} 2 \mathrm{C} 3$ & $\begin{array}{l}3 \\
3^{(3)}\end{array}$ & $\begin{array}{l}\text { Combination of substrate failure, aggregate-paste bond failure and paste failure. Existence of voids on } \\
\text { the fracture surface } \\
\text { Failure in the substrate concrete just bellow the bond-substrate interface (top surface of substrate), } \\
\text { aggregate-paste bond failure, coarse aggregate failure and paste failure. Existence of voids on the } \\
\text { fracture surface } \\
\text { Failure in the bond-substrate interface. } \\
\text { Substrate failure just below the bond-substrate interface (combination of paste failure and aggregate } \\
\text { failure), and bond-overlay interface failure (in the high spots part of the substrate surface, i.e. in the } \\
\text { stand out part of the coarse aggregates) }\end{array}$ \\
\hline B2C4 & $\begin{array}{l}3 \\
3^{(4)}\end{array}$ & $\begin{array}{l}\text { Combination of substrate failure, aggregate-paste bond failure and paste failure. Existence of voids on } \\
\text { the fracture surface } \\
\text { Failure in the substrate concrete just bellow the bond-substrate interface (top surface of substrate), } \\
\text { aggregate-paste bond failure, coarse aggregate failure and paste failure. Existence of voids on the } \\
\text { fracture surface } \\
\text { Failure in the bond-substrate interface } \\
\text { Failure in the bond-overlay interface (located in the high spots part of the substrate surface, i.e. in the } \\
\text { stand out part of the coarse aggregates. A uniform bond-line thickness was not kept. Probably the } \\
\text { remaining water coat of the water used to saturated the surface changed the bond coat thixotropy and } \\
\text { the adhesive drained away from the high spots and into the low spots) and failure in the bond-substrate } \\
\text { interface (levelling to the top substrate surface in the paste and also in the coarse aggregates) }\end{array}$ \\
\hline B3C5 & $\begin{array}{l}1 \\
2 \\
3 \\
3^{(5)}\end{array}$ & $\begin{array}{l}\text { Failure in the substrate concrete just bellow the bond-substrate interface (top surface of substrate), } \\
\text { coarse aggregate failure and paste failure. Presence of voids on the fracture surface } \\
\text { Combination of substrate failure, bond-substrate failure, overlay failure and overlay-bond interface } \\
\text { failure. Existence of voids on the fracture surface } \\
\text { Failure in the overlay-bond interface. Existence of voids on the fracture surface } \\
\text { Bond-substrate interface failure and bond-overlay interface failure (in the high spots part of the } \\
\text { substrate surface, i.e. in the stand out part of the coarse aggregates }\end{array}$ \\
\hline B3C6 & $\begin{array}{l}2 \\
3 \\
3^{(6)}\end{array}$ & $\begin{array}{l}\text { Combination of substrate failure, just bellow the bond-substrate interface (top surface of substrate), } \\
\text { aggregate-paste bond failure, coarse aggregate failure and paste failure. Existence of voids on the } \\
\text { fracture surface } \\
\text { Combination of substrate failure, overlay-bond interface failure (presence of fibres in this region). } \\
\text { Existence of voids on the fracture surface } \\
\text { Combination of bond-substrate interface failure, overlay-bond interface failure. Existence of voids on } \\
\text { the fracture surface } \\
\text { Bond-substrate interface failure and bond-overlay interface failure (in the high spots part of the } \\
\text { substrate surface, i.e. in the stand out part of the coarse aggregates }\end{array}$ \\
\hline
\end{tabular}

${ }^{(1)} \mathrm{B} 1 \mathrm{C} 1{ }^{\prime},{ }^{(2)} \mathrm{B} 1 \mathrm{C} 2{ }^{\prime},{ }^{(3)} \mathrm{B} 2 \mathrm{C} 2^{\prime},{ }^{(4)} \mathrm{B} 2 \mathrm{C}^{\prime},{ }^{(5)} \mathrm{B} 3 \mathrm{C} 4{ }^{\prime},{ }^{(6)} \mathrm{B} 3 \mathrm{C} 5^{\prime}$.

bond strength between concrete substrate and concrete overlay, (b) evaluate the bond performance of three commercially available bond agents, denoted as P1, P2 and $\mathrm{P} 3$, and (c) assess the effect of the loading rate on the pull-off strength. For this purpose, a total of 285 partial-depth cores were tested.

In general, all series have showed a large scatter in the pull-off tensile strength. Nevertheless, all bond coat 


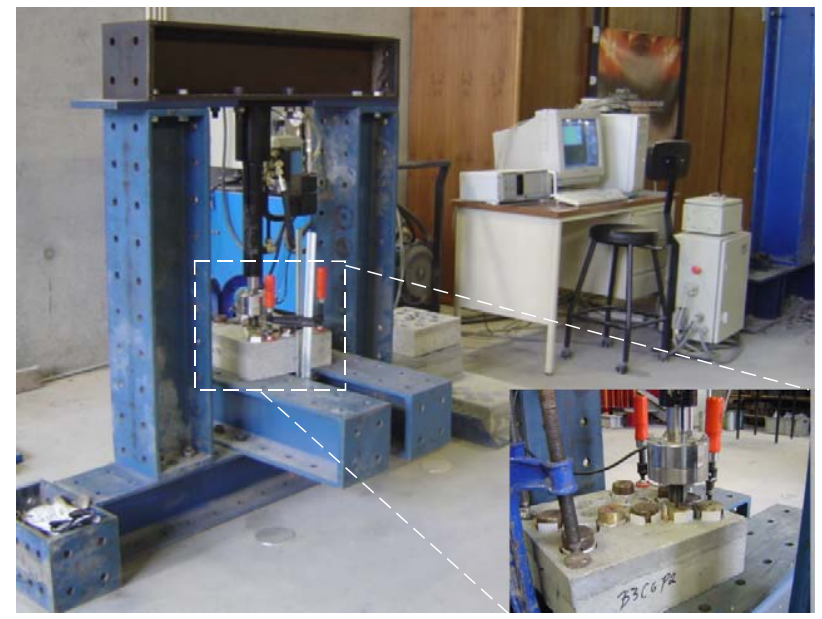

(a)

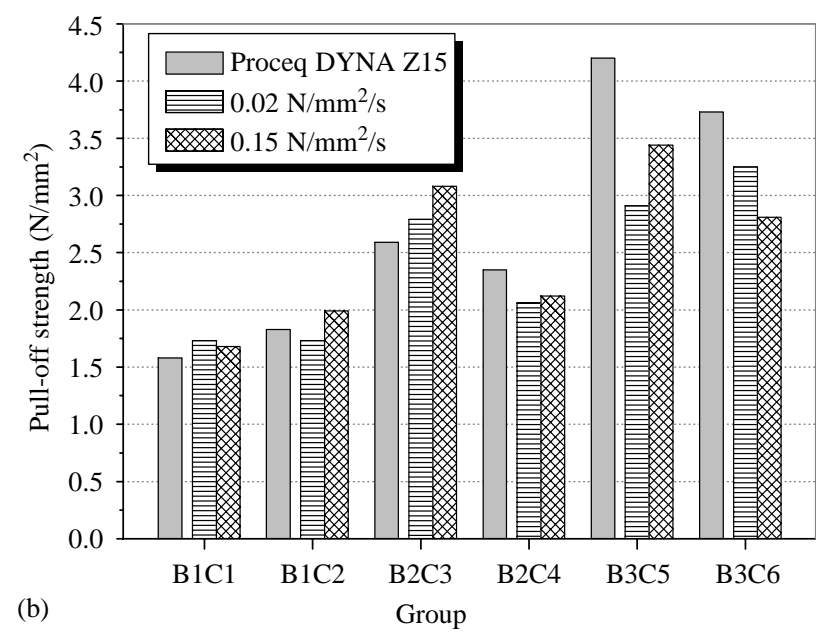

Fig. 6. Influence of loading rate on the pull-off strength: (a) pull-off test set-up for controlled loading rate and (b) comparison of the pulloff strength for different stress rates.

materials exhibited average pull-off strengths higher than $1.12 \mathrm{~N} / \mathrm{mm}^{2}$. For the concrete substrate of low and medium strength, bonded by $\mathrm{P} 1$ or P2 adhesives, there was a clear tendency for concrete substrate failure, which indicates that the substrate concrete was generally the weakest link in the repair system. In this way, the pull-off strength reflects the tensile strength of the concrete substrate.

For P1 and P2 bond materials, the thin SFRC overlay was well bonded to the concrete substrate, and the tensile strength of the overlay has exceeded the tensile strength of the concrete substrate. Evidence of voids and non-uniform steel fibres distribution was observed in some failure surfaces, suggesting that additional attention should be given to the consolidating procedures of the SFRC mixture.

The shape, maximum diameter and strength of coarse aggregates seem to play an important role in the pull-off strength, as for substrate of low and medium strength the crack surface developed at the interface coarse aggregate-cement paste, while at substrates of high concrete strength the coarse aggregate was also crossed by the failure surface.

In general, the failure surface was located at the top of the substrate concrete, just below the bond adhesive. The lower resistance of the top surface of the substrate might explain this behaviour. The procedure carried out in the preparation of this zone might have been responsible for part of this weakness.

The bond product $\mathrm{P} 2$ provided the highest pull-off strength values and, according to the manufacturer, was the more economical, being the best bond product for this type of application.

The results indicate also a trend for an increase of the pull-off strength with the increase of the loading rate, and confirm the difficulty in comparing the results using different test set-ups.

\section{Acknowledgements}

The authors acknowledge the financial support of the Portuguese Science and Technology Foundation (FCT), PhD Grant number SFRH/BD/11232/2002. Acknowledgements are also extended to the companies "Companhia Geral de Cal e Cimento S.A. (SECIL)", Sika S.A., "Central do Pego", "Pedreiras Bezerras", Bekaert NV, "Bettor MBT Portugal Produtos Químicos para Construção S.A.", that have supplied cement, bond products, fly ash, aggregates, steel fibres and superplasticizer, respectively.

\section{References}

[1] Barros JAO, Fortes AS. Flexural strengthening of concrete beams with CFRP laminates bonded into slits. J Cem Concr Compos 2005;27:471-80.

[2] Barros JAO, Dias SJE. Shear strengthening of reinforced concrete beams with laminate strips of CFRP. Proceedings of the international conference composites in constructionsCCC2003, Cosenza, Italy, 16-19 September 2003. p. 289-94.

[3] Barros JAO, Sena-Cruz JM. Strengthening a prestressed concrete slab by epoxy-bonded FRP composites and SFRC overlayer. Proceedings of the seventh international conference on inspection appraisal repairs \& maintenance of buildings \& structures, Nottingham Trent University, UK, 11-13 September 2001.

[4] Barros JAO, Cunha VMCF, Ribeiro AF, Antunes JAB. Postcracking behaviour of steel fibre reinforced concrete. RILEM, Mater Struct 2005;38:47-56.

[5] Knab LI. Factors related to the performance of concrete repair materials, Technical report REMR-CS-12, US Army Corps of Engineers, Washington, DC, March 1988.

[6] Austin S, Robins P, Pan V. Tensile bond testing of concrete repairs. RILEM, Mater Struct 1995;28:249-59.

[7] Vaysburd AM, MacDonald JE. An evaluation of equipment and procedures for tensile bond testing of concrete repairs. Technical report REMR-CS-61, US Army Corps of Engineers, Washington, DC, June 1999. 
[8] Delatte N, Sehdev A. Mechanical properties and durability of BCO and UTW concrete. Proceedings of annual meeting of the TRB, 82th, Washington, DC, January 2003.

[9] ASTM D4541. Standard test method for pull-off strength of coating using portable adhesion testers. American Society for Testing and Materials; 2002.

[10] Sprinkel MM, Ozyildirim C. Evaluation of high performance concrete overlays placed on Route 60 over Lynnhaven Inlet in Virginia. Final report, Virginia Transportation Research Council, Charlottesville, Virginia, 2000.

[11] FHA - Federal Highway Administration. Tensile bond strength of a high performance concrete bridge deck overlay. Field test report, Mobile Concrete Library Project \# 9904, US Department of Transportation home page, 2000. http://www.fhwa.dot.gov/ pavement/mcl9904.pdf (available on March 21, 2003).

[12] Bonaldo E, Barros JAO, Lourenço PB. Bond characterization between concrete base and repairing SFRC by pull-off tests. Report 04-DEC/E-13, University of Minho, May 2004, 57pp.

[13] ACI 503R. Use of epoxy compounds with concrete. ACI manual of concrete practice, Part 5, Reported by Committee 503. American Concrete Institute; 1993 28pp [Reapproved 1998].

[14] Sika. Technical data sheet-construction. Sika-Chemical Industry, S.A., Edition no. 5, 2002. 434pp [in Portuguese].

[15] Faury J. Le Betón. Troisième Édition. Paris: Dunod; 1958.

[16] CEB-FIP Model Code 1990. Design code. Comité Euro-International du Béton, Bulletins d'Information 203-205, Lausanne, Switzerland, 1993.

[17] Dramix: product data sheet. N. V. Bekaert S.A., 1998.

[18] Barros JAO. Steel fibre reinforced concrete behaviour-experimental analysis and numerical simulation. PhD thesis, Faculty of Engineering, University of Porto, 1995 [in Portuguese].
[19] Barros JAO, Figueiras JA. Experimental behaviour of fibre concrete slabs on soil. $\mathbf{J}$ Mech Cohesive-frict Mater 1998;3:277-90.

[20] ACI 503.2. Standard specification for bonding plastic concrete to hardened concrete with a multi-component epoxy adhesive. ACI manual of concrete practice, Part 5, Reported by Committee 503. American Concrete Institute; 1992 5pp [Reapproved 1997].

[21] ACI 503.5R. Guide for the selection of polymer adhesives with concrete. ACI manual of concrete practice, Part 5, Reported by Committee 503. American Concrete Institute; 1997 4pp.

[22] ACI 503.6R. Guide for the application of epoxy and latex adhesives for bonding freshly mixed and hardened concretes. ACI manual of concrete practice, Part 5, Reported by Committee 503. American Concrete Institute; 1992 16pp [Reapproved 1997].

[23] Chmielewska B, Czarnecki L, Krupa P. Influence of selected factors on the results of pull-off tests for industrial floors. Proceedings of the fifth international colloquium-Industrial Floors '03. Technische Akademie Esslingen, January 21-23, 2003.

[24] Proceq, Pull-off tester DYNA Z-16 datasheet. Proceq, S.A., Switzerland, 1998.

[25] BS 1881. Recommendations for the assessment of concrete strength by near-to-surface tests (Part 207). London: BS (British Standard Institution); 1992.

[26] EN 1542. Products and systems for the protection and repair of concrete structures - test methods-measurement of bond strength by pull-off. European standard. CEN, Bruxelas, 1999.

[27] JSCE-E 545. Test method for direct pull-off strength of continuous fibre sheets with concrete. Tokyo, Japan: Concrete Library of JSCE, Japan Society of Civil Engineers; 2000.

[28] Bungey JH, Millard SG. Testing of concrete in structures. 3rd ed. Cambridge, Great Britain: Chapman \& Hall; 1996. 